Volume 7 No.6, June 2018

International Journal of Advances in Computer Science and Technology

Available Online at http://www.warse.org/IJACST/static/pdf/file/ijacst01762018.pdf

https://doi.org/10.30534/ijacst/2018/01762018

\title{
Relation between Total Quality Management and the Performance of E-commerce
}

\author{
RAYA MUSLIM SADIK \\ Business and Information Technology Lecturer. \\ Master of Mechatronics Engineering, University of Technology, Baghdad- Iraq rayasadik@ gmail.com
}

\begin{abstract}
Total quality management is the assurance of quality in the respective field and e-commerce is the buying and selling online. Online sites should and have implemented quality tools that results in better productivity and customer satisfaction. E-commerce is the most frequently used term in many companies because it assures quality control and quality assurance. Quality is controlled and assured by implementation of quality management. When a company launches their online site, the main goal is to assure their quality, to promote their products, to increase the sales and make happy and loyal customers
\end{abstract}

\section{KEYWORDS}

Total quality management - customer engagement customer loyalty - Electronic commerce - online transactions - continuous improvement - Quality assurance - Quality controlling

\section{INTRODUCTION}

Total quality management is the continuous improvement of an organization, in which every employee working in the organization is actively working for the betterment and improvement of it. Quality management is implemented in the firm to meet and maintain the high standards of the organization. The quality management is implemented for the customer satisfaction, customer loyalty, increasing profits and revenues, enhancing work participation, employee involvement, continuous improvement and long term strategic planning. [1]

There are basic tools that have been used in total quality management such as Check-sheet, flowchart, Cause and effect diagram, Scatter diagram, Control chart, Pareto chart, and Histogram. There are 8 fundamental principles of total quality management such as customer focus, leadership, involvement of people or employees, process approach, systematic approach to management, continuous improvement, decision making and last, mutually beneficial supplier relationship. Customer focus is one of the important principles of total quality management, which states that the organization should be very much focused on what customers expect and require. The second principle is leadership and it states that the employees should be fully involved in achieving organization aims and goals. The third principle is involvement of employees which states that the employees working in the organization should be actively engaging him in maintaining firm's high standards. The process approach is the fourth principle of total quality management, which says that the efficient employees carry out the processes and it gives great output. The fifth principle of total quality management is a systematic approach to management, which states that there should be a systematic way to carry out the processes. The sixth principle is a continuous improvement, which says that the organization should be always indulging themselves in the betterment and continuous improvement. The firm should always improve to good from better and the best. The seventh principle is the decision making. Decision-making should be factual and it should be made on the authentic source and the last one is mutually beneficial supplier relationships which state that the organization should maintain their good relations with the suppliers and the partners. These principles make up a quality management, which helps the organization in continuous improvement, better productivity, efficient management and customer satisfaction. [2]

The trend of e-business or e-commerce stated around 1995. E-commerce has derived the form of electronic commerce. E-commerce is the online buying and selling of goods and services. It is through the internet. The business transactions in e-commerce are of different types such as business -to- business, business- to- consumer, consumer- to- consumer and consumer- to- business. A basic difference in a simple business and e-commerce is the online transactions. Now people are using e-commerce through applications and emails. The advantages of e-commerce are we can buy international products, we can easily have access to it, and there is the wide range of products and services online. That is one reason that in today's world, people are more into buying online than from retailers. [3]

As the competition in the online market is increasing day by day, so the online managers are under pressure. Therefore, they have to think of new and 
innovative ways to be the best among all the online sites. The only thing that can sustain the company is the value of their goods and products. They should only work on the quality of the products or services. If they will continuously improve the quality of their products, the customers will be fully satisfied and loyal to their organization. This will result in better sales.

\section{EXAMPLES OF TQM AND ECOMMERCE}

The best example of quality management and ecommerce is eBay and Amazon. EBay and Amazon are the multinational sites of e-commerce and Amazon is the world best site for buying and selling things online. There are some local good online sites to buy and sell things such as Souq.com. They are the most used site in UAE. All the online selling sites make sure of their quality assurance because their customers are everything. They don't want to lose their customers. All they do is deliver the product on time and quality is been suspected. These ecommerce sites are customer focused and they are apply quality management for their customer. It will result in cost reduction, improvement in quality and increasing efficiency. [4]

Quality management in e-commerce sites can be the bar on the top with different options such as about, need help, your account or your cart, online shopping sites might have options of women's clothes, men's clothes, or the things are the selling. This is one way of creating ease for the online customers. This is also a quality management. Secondly, delivering the ordered things on given time or before the deadline is also a quality management. Thirdly, providing the best quality order is also a quality assurance. These all quality management results in customer's satisfaction, customer loyalty and productivity. These websites have a special team for the maintenance of their site. They ensure that the products they are selling are easily available for the customers. Secondly, they should ensure that the ecommerce sites should be mobile friendly because customers want innovation and creativity with easiness. Good websites also ensure that their customers are happy with their service by taking feedback.

\section{RESEARCH QUESTIONS}

1) How is a quality of products that are bought or sold online assured?

2) How implementing quality management will affect e-commerce?

3) How is the relation between total quality management and the performance of ecommerce?

\section{LITERATURE REVIEW}

Total quality management is continuous improvement of the quality of an organization where every person working in an organization should be actively participating in the betterment of his company. Total quality management is based on three qualities; one is quality planning, quality control, and quality improvement. Quality planning to think of your target market and plan according to it, quality control is to maintain and assess the actual performance of the quality and quality improvement is to improve the weak areas. E-commerce is the online buying and selling of product or services. Today, e-commerce sites are into making applications for the ease of their customers. This is one example that they are making sure that the quality is assured.

The competition in online websites has been increasing day by day. Every online business manager should come up with innovative and creative ideas so that the customers stay loyal to them. According to an article by V.Kumar, U.Kumar, and M.A.Sharef (2006), to become the leader in the market, most successful companies are now implementing quality management principles, which are completely customer, focused. Every business in today's world is customer focused. They implement it by those 8 principles of quality management such as leadership, customer focused, involvement of people, process approach, system approach to management, continuous improvement, factual approach to decision making and mutually beneficial supplier relationship. Companies implement these quality tools for the betterment of their management. Quality is all about what fulfills the needs and wants of a customer, conformity to satisfy customers, competitive capabilities that ultimately lead to business performance, conformance to standards, overall requirements of products, services, and processes to satisfy a given need at a suited price.

Total quality management is managing a business and they are customer focused. In this competitive market, E-commerce can only sustain and be successful, if they continuously develop, maintain and sustain the quality of their organization. According to the same article by V.Kumar, U.Kumar, and M.A.Sharef (2006), the organization's motives to transform into e-commerce can broadly be identified as improving efficiency and effectiveness, and ultimately gaining superior competitiveness. These competitive advantages include improving supply chain coordination, differentiating service offer, improving customer service, and entering new markets. [5] 
According to an article by R.P.Mohanty, D.Seth, and S.Mukadam (2007), an e-commerce site can only survive in this competitive market, if the quality of their products and services that determines survival. Excellence in quality helps firms gain customer loyalty and achieve a competitive edge. The ultimate aim or goal of an organization is the customer loyalty and customer satisfaction because they are only means of their sales, profit, and revenue. [6]

There are four types of e-commerce; one is businessto-business, business-to-consumer, consumer-toconsumer and consumer-to- business. All the business transactions in e-commerce need quality management for improving the quality and efficiency. According to an article by T.Sen (2008), by integrating TQM into B2C E-commerce, selling companies can conduct a full Plan-Do-Check-Act cycle. This TQM approach is customer focus, which provides the customer with a quality product at the right time and at the right place. $\mathrm{C} 2 \mathrm{~B}$ with quality approach can help individual sellers contribute and gain the quality benefit of Web site content. The best example of quality management in $\mathrm{C} 2 \mathrm{~B}$ ecommerce site can be Shutterstock or stock images because the consumer wants to buy images for his/her business. Shutterstock is having a quality management that is the reason that many people buy images from them.[7]

$\mathrm{C} 2 \mathrm{C}$ with quality management helps the individual sellers to contribute and gain the quality benefit of Website contents and the government can seek the quality and supportive environment. In this, both purchaser and dealer are the people. The best example of $\mathrm{C} 2 \mathrm{C}$ ecommerce sites are EBay and amazon. The main reason of implementation of quality management in ecommerce business is interactivity, product offering, level of trust, rate of growth and adoption, networking, level of commitment, and payment options.

The quality management helps the individual sellers to contribute and gain the quality benefit of Website contents through the reliable customer's and efficient work. Amazon is considered as the best online ecommerce site because of its products quality and for the efficient delivery service. They sell everything. This attracts the customers of every age. The quality is assured by the customer's satisfaction and they are only satisfied when they provided by effective services.

If we implement quality management in B2B it will result in low purchasing costs, reduced inventory and warehouse costs, enhanced efficiency of logistics and procurement, lower marketing cost, and improved sales in the market. The best example of B2B ecommerce site who have implemented quality management can be Flex fire LED. They provide an amazing website for the businesses and they provide variety of light designs to different businesses. They have a customer chat support on their page for solving buyer's problems. This is one way of assuring quality.

The performance of e-commerce will become better with the help of implementing total quality management and this will have the positive result such as more productivity, more efficiency, effective managerial approach and customer satisfaction.

The ecommerce websites take care of their reputation and customer loyalty by making blogs and publishing articles about them so that people will be more attached to them. They take advantage of SEO (search engine optimization) for their website. Thirdly, they go very active on social sites and call bloggers for the media coverage. This is one new way of promoting anything named as PR (Public relations). Lastly, they encourage their happy customers to post comments and give 5 star rating. These things actually help in maintaining the reputation and creating and hype of the website.

\section{METHODOLOGY}

I have conducted this research through distributing the questionnaire among 10 students and 5 faculty members of University of Dubai. The questionnaire consists of 7 different types of questions which include yes or no questions, open-ended questions and multiple choice questions as well.

\section{PARTICIPANTS}

The questionnaire is distributed among the 15 people, 5 were boys, 5 were girls and 5 were the faculty members of University of Dubai business department, majors in marketing. The main aim was to know there point of view on the relation between total quality management and the preformation of ecommerce, the performance after applying quality tools in e-commerce websites.

\section{RESULTS}

The name of my research paper is "relation between total quality management and the performance of ecommerce". The first question I asked in the questionnaire survey was "Have you ever used or purchased anything from e-commerce website?" I gave an option of yes or no for this question. as shown in Figure 1 thirteen out of fifteen people choose yes and two people choose No. One was a teacher and one was a student 


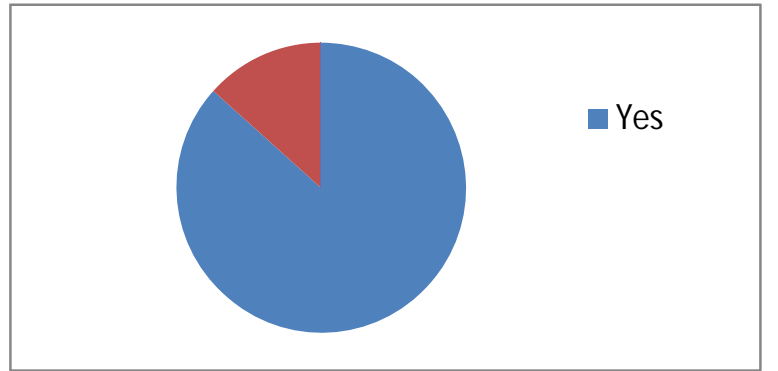

Figure (1) Participations Response to the First Question

When I asked for a reason that why they haven't used any e-commerce website yet, they replied to this that they don't trust the quality of the online purchase.

The second question in questionnaire survey was "How was your experience with online shopping from e-commerce website?" It was a multiple-choice question. I gave four options for this question such as excellent, good, bad and very bad. As shown in Figure 2 six people voted for excellent, two people voted for good, four people voted for bad and three people voted for very bad.

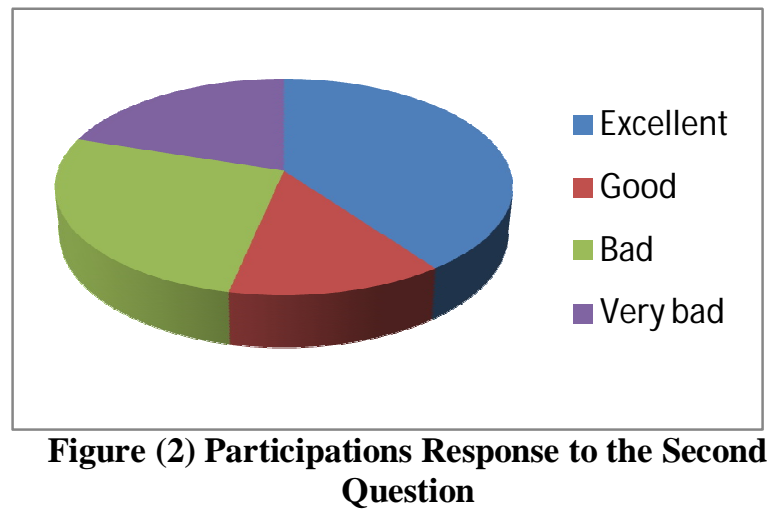

The third question in research survey was "What do you think that why you're online experience is not that good?" There were different answers to this question because it was an open-ended question. The most frequent answer that I got was that online shopping experience depends on few variables. If you order from a well-reputed site and mostly international sites than there is no chance of compromise and quality and if we order from local vendors, which have no reviews or proper setup than there, are chances of some quality issues. Therefore, Amazon and Ali express has been rated the best sites for online shopping.

The fourth question in my research questions was "How is a quality of products that are bought or sold online assured?" This question was again an openended question and the reason I asked this was to check student's general knowledge. The answer I frequently got for this question was that quality of products bought online could be assured by ordering from a well-reputed website that has a good brand name and images it may be local or international like again Amazon, Ali Express, eBay and Nishat Linen.

The fifth question that I asked in the questionnaire was "How implementing quality management will affect e-commerce?" It was again an open-ended question. The answer I constantly got for this question was that quality management could assure good e-commerce when a website or a company will ensure total quality management than there will be very less chance of compromise on quality so their brand image or corporate image will improve and people will more order from the website without any hesitation.

The sixth question I asked in the questionnaire survey was "How is the relationship between total quality management and e-commerce?" There is a direct relationship between quality management and e-commerce. If e-commerce website implements quality management, there will be no compromise on the quality of the product and this will help them in improving their brand image and ultimately result in customer satisfaction and more people will buy from their website.

The last question I asked in the survey was "How can you improve the experience of e-commerce?" and it was a multiple-choice question. I have four options for this question. The options were improving the quality of the product, quick delivery, good applications and all of above. As shown in Figure 3 five people voted for improving the quality of the product and five people voted for all of above whereas four people voted for quick delivery and only one person voted for good application.

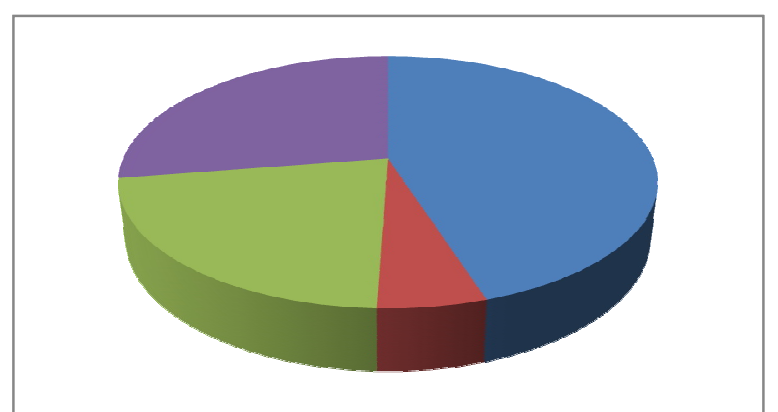

Figure (3) Participations Response to the Last Question

Therefore, these were the result that I got from the questionnaire survey.

\section{CONCLUSION}

There is a direct relationship between total quality management and the performance of e-commerce. In this competitive market and when every brand is 
RAYA MUSLIM SADIK, International Journal of Advances in Computer Science and Technology, 7(6), June 2018, 27-30

using electronic service, a company should implement quality management that will assure the quality of the product and service. It is important for a company to have quality management. This will result in customer satisfaction, managerial efficiency, continuous improvement and customer loyalty. When a customer will be fully satisfied with an e-commerce website, they will not hesitate from buying or selling anything from that website. For example, Amazon is the best e-commerce website because they have an easy checkout process and are responsive, mobilefriendly application. It has created an ease for the users and that is the reason that Amazon is the best ecommerce website. Thousands of people buy and sell things through Amazon.

\section{REFERENCES}

[1] http://shodhganga.inflibnet.ac.in/bitstream /10603/ 108436/10/10_chapter\%201.pdf

[2] http://blog.pilgrimquality.com/iso90012015quality-mgmt-principles/

[3] http://searchcio.techtarget.com/definition/ecommerce

[4] https://services.amazon.in/resources/sellerblog/best-e-commerce-site-design-in-india.html

[5] Kumar, V., Kumar, U., \& Shareef, M. A. (2006). Implementation of Quality Management Practice in E-Commerce. In ASAC. (Literature review, page 6)

[6] Mohanty, R. P., Seth, D., \& Mukadam, S. (2007). Quality dimensions of e-commerce and their implications. Total Quality Management \& Business Excellence, 18(3), 219-247. (Literature review, page 6) https://doi.org/10.1080/14783360601149992

[7] Şen, T. (2008). Total quality management in ecommerce. (Literature review, page 8) 